\title{
Vertical and horizontal accountability on disaster preparedness and response of two highly urbanized cities in Metro Manila, Philippines
}

\author{
Marlon $\mathrm{Era}^{1}{ }^{*}$ \\ ${ }^{1}$ De La Salle University, Manila, Philippines
}

\begin{abstract}
This paper focuses on the accountability of disaster preparedness and response of two cities in Metro Manila, Philippines. The paper draws a lesson from the experiences of two highly urbanized cities in Metro Manila and how coordinated efforts in disaster preparedness and response among the members of the City Disaster Risk Reduction and Management Councils (CDRRMC) were accounted for. This paper provides a deeper understanding of how city governments fulfill their commitments and responsibilities to disaster victims during disaster preparedness and response. This study utilized key informants interviews and focus group discussions among key members of CDRRMC and review of existing laws and relevant policies. The upward vertical accountability is well established as this involves members of the City DDRM Councils as the council members are accountable to their respective City Mayors. Downward vertical accountability is not well defined as this refers to the accountability of DRRM frontline service workers to the disaster victims. The horizontal accountability among members of the City DRRM Councils is yet to be established as this involves different department heads who are at the same level of power and authority. The paper provides fresh insights on the vertical and horizontal accountability in disaster governance of cities in Metro Manila.
\end{abstract}

\section{Introduction}

Vertical and horizontal accountability are forms of accountability and are facets of democracy and good governance. These two forms of accountability exist in disaster risk reduction and management (DRRM). Due to the severe impact of disasters experienced by the affected countries, it is imperative to establish accountability in disaster governance as it promotes the stakeholders' fulfilment of responsibilities.

Globally, there have been significant achievements in DRRM. However, there remain certain issues that nations encounter in disaster governance. First, some countries fail to demonstrate good governance, which hampers the effective implementation of DRRM. Second, there can be challenges brought by having multiple disaster governance paradigms in the processes of DRRM.

Firstly, countries become vulnerable to disasters when they suffer from having bad governance. National development and disaster risk reduction efforts are cultivated when features of good governance, i.e., "participation, consensus, accountability, transparency, responsiveness, effectiveness, efficiency, equity, inclusivity and rule of law" are present in a country [1] (Khotami, 2017). Conversely, [2] Van Niekerk (2015) pointed out that carrying out effective disaster governance can be difficult when such features of good governance are non-existent in a country. The susceptibility to disasters results from institutional failure-which is associated with bad governance. Institutions are comprised of various state and non-state actors that make up the governance structure that formulates public policies and provides the needs of the citizenry. When such a governance structure fails to deliver services to the public, consequently, it results in institutional failure, and ultimately exposes the nation to disaster risk [3] (Ahrens \& Rudolph, 2006).

Secondly, governments can encounter difficulties in the emergence of multiple paradigms and paradigm shifts in DRRM. Disaster governance paradigms, which guide plans and policies, have changed and shifted during the course of nations' plethora of disaster experiences. However, some countries struggle in handling multiple and shifting disaster governance paradigms. For instance, international institutions advocate for a shift in disaster management paradigm - from "'response and recovery" to "prevention and preparedness""; this paradigm shift is represented through Disaster Risk Reduction (DRR). [4] Jones et al. (2015) explained the difficulty in mainstreaming DRR into national development activities,

* Corresponding author: $\underline{\text { marlon@dlsu.edu.ph }}$ 
which requires shifting the paradigm to prevention and preparedness. This is because disaster managements are still response-oriented than prevention-oriented. This can also be difficult for nations that lack resources to achieve this [5] (Jones et al., 2015). Another example is the case of Nepal where various state and non-state actors uphold their paradigms in disaster governance. The differences in paradigms among these actors result in the division of resources, competition among them, and struggles in campaigning for their paradigm [6] (Vij et al., 2020).

Specifically, some developing countries in Asia and some parts of the West, also deal with issues in DRRM. The local governments, who are a fundamental unit in disaster governance, lack the capacities to administer management in disasters. Likewise, some countries suffer the poor legislation that supports DRRM. Also, there have been ambiguous hierarchical structures and delegation of responsibilities among stakeholders in some nations, which entail difficulties in DRRM.

The local government units play a great role in disaster governance. Local or regional areas of a country are the ones generally hit by disasters, and therefore they typically carry out the activities to handle disasters [7] (Jones et al., 2015). However, there is a profound lack of capacities in administrative, organizational, financial, and political aspects in developing countries [8] (Ahrens \& Rudolph, 2006). In the case of Nepal, the organizations at the local level struggled with a deficiency in financial and technical resources. This resulted in the inability to deal with large-scale disasters and to implement disasterrelated activities. Such insufficient capacity was attributed to a lack of autonomy as they were restricted to making their own decisions and mostly depended on assistance from higher-level organizations [9] (Choudhury et al., 2019). The issue of lack of capacity at the local level is also evident in India where human, material and financial resources were inadequate. However, in contrast, in their case, decentralization or having autonomy empowered the local government and general population [10] (Pal \& Shaw, 2018). Furthermore, lack of capacity is also suffered by other countries such as Nepal and Timor-Leste [11] (Jones et al., 2014 \& [12] Cook et al., 2019).

Legislation is an integral part of disaster governance, as it "provides the framework around which strategies to build risk reduction into development and reconstruction activities can be empowered" [13] (Pal \& Shaw, 2018). However, legislation for disaster governance aiming for public development tends to not be prioritized due to other matters, such as socioeconomic issues being prioritized instead [14] (Samutereko, 2021) as well as deficiency in financial resources [15] (Pal \& Shaw, 2018). [16] Samutereko (2021) explained that, in Zimbabwe, they have a weak institutional basis for DRR at the local levels. Disaster legislation has not been prioritized in the country. Thus, he pointed out the need to revise the country's disaster legislative framework in which vulnerability reduction and community resilience have to be taken into account to tackle disasters effectively. Similarly, in Pakistan, [17] Deen (2015) called for the government to formulate policies that help decrease vulnerability to disasters as well as to prioritize disaster preparedness and response at the national level.

The difficulties exist among state and non-state actors in terms of hierarchical structure and distribution of responsibilities. These actors include government institutions, non-governmental organizations (NGOs), international non-governmental organizations (INGOs), and other civil society actors. [18] Jones et al. (2015) discussed the evolution of disaster risk governance wherein delegation of influence and responsibility among different stakeholders has been "reoriented upward, outward, and downward." It then creates vagueness as to "who governs DRR?" This is somewhat reflected in the case of Uganda where people "were lost in the complex hierarchical structure" and there was a lack of clarity of the responsibilities and roles vested on the actors involved in disaster management [19] (Maes, 2018). This issue is also evident in the case of Nepal where it was "difficult to locate centers of power or identify who is leading the [disaster risk reduction] process" [20] (Jones et al., 2014).

The Philippines also experiences certain problems concerning the implementation of DRRM. In particular, issues in the local government in the Philippines have been present. [21] Sonny \& Manejar (2018) explained these issues. For instance, the DRRM was not mainstreamed within the local government as manifested by certain misalignments between LGUs' local plans with the major planning documents for DRRM. In addition, the number of permanent appointees does not meet the minimum staff number per LGU, as suggested in the policy. Also, the mandated 5\% funds of DRRM allocated for the LGUs were underutilized.

In the case of Typhoon Yolanda, Sonny \& Manejar (2018) discussed several problems that occurred as the government tackled the disaster. First, the local government units (LGUs) were "sidelined three years after RA 10121 was passed in the wake of Yolanda." Second, command responsibility and the persons who were supposed to be in charge of decision-making were ambiguous. Third, despite the issue of ambiguity at hand, multiple actors who were involved did not coordinate among themselves. Lastly, funds from the government were not granted to municipal mayors, and funds from NGOs were delayed due to the bureaucratic processes [22] (Sonny \& Manejar, 2018). Furthermore, the LGUs themselves were ravaged by the impact of the typhoon and were immobilized at the time and the government officials at the higher level presided. However, during the disaster, there had been "too much politicking" as those officials who took over had arguments among themselves and were sensationalized publicly [23] (Blanco, 2015).

\subsection{Accountability}

Critical to that of a developing democracy is the delivery of much-needed services to its citizenry. Hence, accountability connotes both the responsiveness of elected officials to citizens' demands and the responsibility that government officials have to act upon those preferences [24] (Acosta et al., 2010). [25] Amaratunga et al. (2016) stated that "[accountability] 
rather than being a bureaucratic or legal term, is about improving democratic processes, challenging power and claiming citizenship." It is also instrumental in establishing public trust towards the performance of the government [26] (Khotami, 2017). Accountability is also a key feature in building good governance [27] (Khotami, 2017 \& [28] Bovens, 2007). Governance refers to the decision-making and implementing processes among governments and public or private institutions [29] (Yap, 2007). As stated earlier, good governance includes "participation, consensus, accountability, transparency, responsiveness, effectiveness, efficiency, equity, inclusivity and rule of law" [30] (Khotami, 2017).

The concept of accountability indicates a relationship between, at least two types of actors, "a principal" who entrusts (a task or responsibility) to "an agent" for the sake of the principal [31] (Acosta et al., 2010). Accountability takes various forms, two of them being-vertical accountability and horizontal accountability. Vertical accountability is a principal-agent relationship in which the principal (state's citizenry) holds the agents (governments) accountable for their actions. Horizontal accountability involves various institutions of different government branches that hold each other accountable and monitor so that no institution exhibits abuse of power and such [32] (O'Donnell, 1998 as cited in Acosta et al., 2010). In addition, accountability entails concurrence among organizations and individuals on their assigned roles, tasks, and responsibilities as well as reporting on relevant actions [33] (Amaratunga et al., 2019).

There are two mechanisms in pursuing accountability in relationships between citizenry and government and government performance. First, Political Mechanismreferring to a specific form of relationship between elected government officials being directly responsible for their public action, including but not limited to the provision of public goods. This presents an opportunity for voters to reward or sanction their government officials by granting them the right and duty to re-elect or not their political representatives out of office due to their vertical linkage. This is regardless of whether these officials have complied or defected with the electoral mandate [34] (Manin et al., 1999). Second, Social Mechanisminvolves social dynamics and whose processes that may not take place via formal electoral procedure but through street protests, mobilizations, and social media. The main feature of this mechanism is to achieve direct influence on government officials to acquire the desired result of effective government action. Albeit its effectivity is short-termed and not binding, it applies to services that cover, health, sanitation, water, transportation, wages, etc. [35] (Acosta et al., 2010).

\subsection{Dimensions of Accountability}

Accountability encompasses financial, legal, and social dimensions. These dimensions of accountability are necessary as a part of the democratic venture and on the account of good governance. First, financial accountability is the provision of relevant information and reports on financial activities and the performance of the stakeholders [36] (Schiavo-Campo and Tomasi, 1999 as cited in Zeyn, 2018). It also connotes the obligation of the stakeholders to manage the funds responsibly [37] (Madiasmo, 2002 as cited in Zeyn, 2018). In the context of public financial accountability, at the core of it is "the checking and balancing of potential abuse of power by public officials to limit the potential for corruption of public offices and officials" [38] (Khaile \& Davids, 2020).

In addition, an important activity that strengthens financial accountability is a financial audit. It is the examination of financial statements to ensure transparency of stakeholder actions [39] (Zeyn, 2018). [40] Dewi et al. (2019) also pointed out that the information quality of financial statements influences financial accountability. Therefore, a financial audit is an important aspect of the institutional management function.

Second, legal accountability involves processes that "seek to ensure that government delivers on electoral promises, fulfills the public trust, aggregates and represents citizens' interests, and responds to ongoing and emerging societal needs and concerns" [41] (Brinkerhoff, 2017). It involves elected public officials' fulfillment of their duties, such as providing public needs [42] (Acosta et al., 2010). In addition, within such dynamics, citizens observe the officials' performance in terms of establishing and executing policies, building public confidence, and carrying out societal rules [43] (Brinkerhoff, 2017).

Third, [44] Amaratunga et al. (2016) argued that accountability in DRR is "more social than political." Social accountability drives increased participation of citizens in checking the governments and their actions in fulfilling their responsibilities [45] (Amaratunga et al., 2016). Social accountability moves beyond formal ways, i.e., elections, (contrary to political accountability) but rather it is "a continuous relationship of citizen demands" through street protests and mobilizations, public naming and shaming, signing of petitions, etc." [46] (Acosta et al., 2010). Its salient feature is to get direct answers from the government as demanded by the citizens [47] (Acosta et al., 2010).

\subsection{Accountability in Disaster Risk Reduction and Management}

Accountability is invaluable in ensuring the government's provision of public goods and services and is a key feature of good governance. Its role extends to DRRM. The stakeholders who are in charge of governance obligations are held accountable to guarantee successful DRRM [48] (Amaratunga et al., 2019). Accountability in DRRM aims to enable scrutiny and understanding of the measures taken by involved actors and the actors themselves [49] (Amaratunga et al., 2016).

Due to the severe losses brought about by disasters, the key stakeholders' performance in DRRM must be enhanced. This can be achieved by establishing systematised effective accountability mechanisms. These mechanisms are ought to be conducted during the various phases within the cycle of disaster management (i.e., response, recovery, rehabilitation, reconstruction, 
prevention, mitigation, and preparedness) [50] (Amaratunga et al., 2016). Moreover, according to [51] Amaratunga et al. (2019), accountability can be ensured through: mainstreaming DRR into overall national policies, enabling legislation, institutional development, acquiring adequate resources, empowerment of stakeholders, and regular monitoring, evaluation, and review.

There are international frameworks that guide the governments in formulating policies and mechanisms for DRRM. Some of the widely-recognized frameworks globally are Hyogo Framework for Action (HFA), Sendai Framework for Disaster Risk Reduction (SFDRR) 20152030, Climate Change Adaptation (CCA), among others. These frameworks emphasize the importance of accountability. For example, the SFDRR acknowledges the significant role of the government in fulfilling their responsibilities, particularly, in dealing with disaster risks and thus it recognizes the importance of holding them accountable for their actions [52] (Amaratunga et al., 2019). In the Philippines, Republic Act 10121 mandates the governments to practice transparency and accountability as attributes of good governance [53] (Republic Act No. 10121, 2010).

\subsection{Policy on DRRM Accountability}

The knowledge and experiences gained from venturing to prevent, mitigate, prepare and respond to disasters have been shared among international entities and nations [54] (Amaratunga et al., 2019). Frameworks containing lessons learned and guidelines have been created to direct governments in establishing effective DRRM. The Sendai Framework for Disaster Risk Reduction (SFDRR) 20152030 recognizes the State's principal role in achieving disaster risk prevention and reduction. Together with the State, it emphasizes the role of other stakeholders, stating that:

Disaster risk reduction and management depend on coordination mechanisms within and across sectors and with relevant stakeholders at all levels, and it requires the full engagement of all State institutions of an executive and legislative nature at national and local levels and a clear articulation of responsibilities across public and private stakeholders, including business and academia, to ensure mutual outreach, partnership, complementarity in roles and accountability and follow-up [55] (Sendai Framework for Disaster Risk Reduction 2015-2030, 2015).

In the Philippines, the Philippine Disaster Risk Reduction and Management Act of 2010 (Republic Act No. 10121) is the national law that lays out the policies, plans, and programs that are to be taken when dealing with disasters (Republic Act No. 10121, 2010). The law also assigns the government departments with responsibilities and respective agencies to be supervised. The highestlevel government agency that is organized by the law is the National Disaster Risk Reduction Management Council (NDRRMC) or National Council that supervises disaster governance [56] (Republic Act No. 10121, 2010 \& Opulencia-Calub et al., 2017). It is administered by the
Office of the Civil Defense under the Department of National Defense (DND) which oversees the planning, training, coordination, emergency response, and operational support in DRRM [57] (Opulencia-Calub et al., 2017). The Council is mandated to create "an enabling environment for government action at all levels, and embed a culture of continued accountability to and communication with people affected by a disaster" [58] (Opulencia-Calub et al., 2017). Other departments include those who supervise the four thematic areas of disaster in RA 10121, namely, the Department of Interior and Local Government for preparedness, Department of Social Welfare and Development for a response, Department of Science and Technology for prevention and mitigation, and the National Economic and Development Authority for rehabilitation and recovery [59] (Republic Act No. 10121, 2010).

Furthermore, the law provides directives for the NDRRMC, in particular, the civil defense offices, to assist the regional and local councils in disaster governance (Opulencia-Calub et al., 2017 \& Blanco, 2015). The law mandates the organization of offices, that is the Local Disaster Risk Reduction and Management Office (LDRRMO), at all local government levels: provincial, city, municipal, and barangay (Republic Act No. 10121, 2010). These local offices are to administer the DRRM activities and plans and capacity-building and knowledge management for DRRM [60] (Opulencia-Calub et al., 2017).

\section{Objectives and Method}

The study initially documented the horizontal and vertical accountability of Cities of Quezon and Muntinlupa to appraise if certain provisions (Sections 12, 19 \& 20) from Republic Act 10121 were enforced by the Local Disaster Risk Reduction Management Offices (LDRRMOs).

Table 1 FGDs Conducted in Muntinlupa and Quezon City

\begin{tabular}{|c|c|c|}
\hline Date & Participants & Venue \\
\hline $\begin{array}{l}\text { August } 30, \\
2017\end{array}$ & \begin{tabular}{lr} 
City Disaster & Risk \\
Reduction & and \\
Management & Office; \\
City Health & Office; \\
Department & of \\
Education; & City \\
Engineering Office; City \\
\multicolumn{2}{l}{ Social Services }
\end{tabular} & $\begin{array}{l}\text { Muntinlupa } \\
\text { City Hall }\end{array}$ \\
\hline $\begin{array}{l}\text { September } \\
2017\end{array}$ & 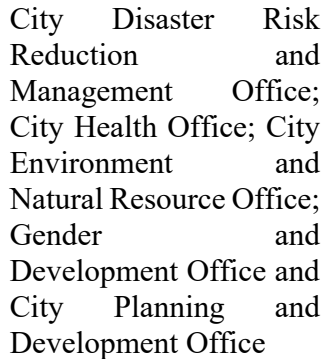 & $\begin{array}{l}\text { Quezon City } \\
\text { Hall }\end{array}$ \\
\hline
\end{tabular}

Given that much of the LDRRMO's performance presented and much-publicized are those derived from its upward and downward accountability. Study findings 
were also derived from the Focus Group Discussion (FGD) conducted in both cities in August and September 2017 respectively which were participated by the members of the Disaster Risk Reduction Management Councils (Table 1). Likewise, selected representatives of the two cities were interviewed as key informants. All data about the research inquiry were enumerated according to questions posed by the research. Questions ranging from their role identification to their accountability were documented to appraise the existing condition and status in both cities regarding their respective DRRM councils. However, the last set of three (3) questions revealed the emerging pattern/s from which to address the concerns and issues derived from both study areas.

\section{Findings}

Particular findings revolved around identifying the thematic groupings involved in the DRRMC; their roles and responsibilities; performance rating of their respective committees and council in the implementation of the disaster mitigation and response in the last five (5) years; the major accomplishments as a committee in said implementation; the issues and challenges encountered by their committees in said implementation; level or degree of accountability with regard to the respective committees actual duties and responsibilities; the feedback mechanism of each committee in the city disaster response and mitigation; presence of a feedback mechanism of DRR in the city; factors facilitating accountability in the performance of disaster response and mitigation in the city; factors that hindered accountability in the performance of disaster response and mitigation in the city; and what the recommendations are to improve accountability in the DRRM council especially in the implementation of disaster response and mitigation.

\subsection{Accountability in Disaster Preparedness and Responses}

The existing conditions in the two (2) cities relative to their accountability in Disaster Preparedness and Response (DPR) were determined. The DPR includes how the City Disaster Risk Reduction Management Office (C/DRRMO) accounts to their Superior or Donor in the execution of their functions. For both Quezon City and Muntinlupa City, DRRM Council representatives claimed that they are accountable to the Office of the Mayor since that office is the one making final approval of the DRRM funds release and utilization. However, the City Health Office (CHO) of Muntinlupa clarifies that in the case of in-kind donations, $\mathrm{CHO}$ representatives view no need for accountability for such type of donation.

Other responses elicited from the same FGDs regarding accountability albeit are concerning disaster victims and their families. There were different sets of responses from both Quezon City and Muntinlupa, as documented by the research team. Representatives from two (2) (Environment and Engineering) of the three (3) respondents from the Quezon City DRRMO claimed no accountability as they provide only services to DRRMO responders and are not front liners. The $\mathrm{CHO}$, by contrast, concur being accountable towards disaster victims as they are in direct contact with the beneficiaries of their health services.

The majority of the participants from Muntinlupa declare that the DRRMO, like in any LGUs, aims for zero casualties, making the office accountable to every victim. This was affirmed by the Medical Controller and Physician of the DRRMO who backed up his claim that all barangay personnel of 9 barangays of Muntinlupa was trained to respond to emergency cases as an initial action towards zero casualties.

Concerning the accountability with other members of the City DRRM Council, all respondents from Muntinlupa FGD reveal that they have yet to establish accountability with other members of the City DRRM Council. Participants declare that the issuance of accountability within said council is subject to further discussion and without prejudice being that the establishment of the DRRMO is still in its nascent stage.

However, the Philippine National Police and the Department of Education, both members of the DRRM council, mention the various modalities in which they can be held accountable. For example, an administrative case may be filed against the Police Officer of the Philippine National Police (PNP) at their headquarters should they encounter an erring police officer. For the Department of Education, their modality is to rely mostly on their Brigada Eskwela,(school brigade) which operates before the school openings only, and on the teachers for the rest of the year. The City Health Office claims open lines of communication between the CHO staff city and barangay concerning the DRRM program. Meanwhile, the City Engineering Office has yet to determine their DRRM accountability having recently joined the Council.

Quezon City DRRM council members were asked about responsibilities during disaster preparedness and response. The Head of the City Engineering Office cites no accountability within the DRRM Council, while the DILG representative notes its accountability including the Bureau of Fire Protection and the Quezon City Council Secretary.

The explanation is to ensure that information given to the Department of Interior and Local Government, coming from regional and national channels, is expected to be coordinated with local services. A representative from the Gender and Development (GAD) department confirms its accountability within the council but it is not proactive. The City Health Office $(\mathrm{CHO})$ reports feedback among members of the council and works very closely with each member. In addition, they feel accountable to the Council and free and open to suggestions.

\subsection{Vertical Accountability among City DRRM Councils}

Results of the study indicated the various conditions which substantiate the two (2) types of accountability. Beginning with the vertical accountability for the Quezon 
City Disaster Risk Reduction Management Council, all FGD participants signified their familiarity with their respective committees in the City's DRRM Council namely: Disaster Preparedness, Search and Rescue, and Prevention and Mitigation. The Department of Environment and Natural Resources (DENR) representatives are included as part of the operating team handling relocation emergency, relocation and rehabilitation, and emergency and rapid assessment operating team. Adding the participation of the Engineering Department-National Capital Region (NCR) that provides the services of intervention, restoration, and post-rehabilitation of facilities, aside from the Technical Assistance provided to the DRRMO, has also been documented.

\subsection{Horizontal Accountability among City DRRM Councils}

The existing horizontal accountability noted in this particular study is according to set standards by the government; the main to this is its observance to prescribed national standards. Horizontal accountability has a basic core of standards set by the Commission on Audit (COA) and those prescribed by government awarding bodies i.e. KALASAG and Seal of Good Local Governance as well as standards as suggested concerning internal operations (i.e. Annual Investment Plan) of its local government units. This means all government officials and employees under each department, division, down to its local units are cognizant of their accountability towards their respective department heads, mayors, headquarters, and the like.

On the matter of horizontal accountability for the City of Muntinlupa, all members of the city DRRM council are aware of their accountability to the City Mayor and the modalities in which this is enforced. Regarding accountability to disaster victims, who are the clients or beneficiaries of various disaster response interventions, during the FGD, many of the participants declared their aim for Zero casualty-making the City DRRMC accountable for every victim. Meanwhile, from the Quezon City DRRMC, most of those who recognized accountability are those teams in direct contact with beneficiaries or front-liners such as the Officer-in-Charge for Disaster, Community Health Office, and the DRRMO. The rest of the DRRMC members claimed to not view accountability to the victims as they do not have direct contact with the disaster victims.

Based on the documented responses from both Focus Group Discussion of Quezon City and Muntinlupa, both groups are unclear of their accounts within their respective councils. What is mostly indicated from their responses is their accountability in the upward pattern and that is leading towards their City Mayors and their respective department heads (i.e. DILG Secretary, PNP Chief, etc.). There is also the lack of appreciation for downward vertical accountability among the council members for their target clients which is seemingly treated as part of the demographics. The quality of feedback needs to be evaluated to provide better service to its constituents with a set of standards with regards to their feedback mechanism to change the culture of demography/statistics of its constituents and provide quality government service.

\section{Conclusion}

Good governance recognizes the fact that accountability aims to ensure an improvement in the delivery of public services, measuring performance, and providing incentives to achieve targets and sanctions in case of nonperformance among institutions. It forms a part of a whole among the main characteristics of good governance to which the desired results is to promote community confidence assuring the community that its local government will act and pursue the community's overall interest regardless of dissenting opinions among members. This also serves as a reminder for local governments that they are acting on behalf of their community to help them understand the importance of having open and ethical processes which adhere to the law and stand up to scrutiny.

Just as the Philippine government struggles to evolve into a new democracy, paradigm shifts relevant to government and government service continue to occur. In the context of disaster preparedness and response, certain improvements could be introduced in the bureaucracy particularly in the sector of government service. This is particularly in the areas of downward vertical accountability in terms of how the government direct service workers can be accountable to the disaster victims and families. In the same token, horizontal accountability has yet to happen including among members of the different local special bodies like the City Disaster Risk Reduction and Management Councils wherein, there is no clear accountability mechanism or procedure is available to make members more accountable. Unless a better understanding of the cause of horizontal accountability is better appreciated between and among the main actors in fulfilling their respective agencies mandate, institution blaming will continue without leading to likewise the maturity for government bureaucracy and service delivery. Having both vertical and horizontal accountability established and properly observed by both parties in the disaster preparedness and response platform, we may expect to see more transparent and accountable governance and happier and more resilient citizens

\section{References}

1. S. C Opulencia-Calub, E. M. Luna, J. G. J., Molina, Pontejos, G. G., \& Chico, J. S. (2017). Tools, platforms, and mechanisms to support accountability to disaster- Khotami, M. (Eds.). The Concept of Accountability in Good Governance. Atlantis Press. (2017)

2. Van Niekerk, Disaster risk governance in Africa: a retrospective assessment of progress against the Hyogo Framework for Action (2000-2012). Disaster Prevention and Management, 24(4), 397-416. (2015). 
3. J. Ahrens, \& P. M. Rudolph, The importance of governance in risk reduction and disaster management. Journal of Contingencies and Crisis Management, 14(4), 207-220 (2006).

4. S.Jones, B. Manyena, \& S. Walsh, Disaster risk governance: evolution and influences. In J. F. Shroder, A. E. Collins, J. Jayawickrama (Eds.), Hazards, risks and disasters in society (pp. 45-61). Academic Press. (2015).

5. S. Jones, B. Manyena, \& S. Walsh, Disaster risk governance: evolution and influences. In J. F. Shroder, A. E. Collins, J. Jayawickrama (Eds.), Hazards, risks and disasters in society, 45-61. Academic Press. (2015).

6. Vij, S., Russell, C., Clark, J., Parajuli, B. P., Shakya, P., \& Dewulf, A. Evolving disaster governance paradigms in Nepal. International Journal of Disaster Risk Reduction, 50, 1-8 (2020).

7. S. Jones, B. Manyena, \& S. Walsh, Disaster risk governance: evolution and influences. In J. F. Shroder, A. E. Collins, J. Jayawickrama (Eds.), Hazards, risks and disasters in society 45-61. Academic Press. (2015).

8. J. Ahrens, \& P. Rudolph, M. The importance of governance in risk reduction and disaster management. Journal of Contingencies and Crisis Management, 14 (4), 207-220.

9. M. U. I. Choudhury, M. S. Uddin, \& C. E. Haque, "Nature brings us extreme events, some people cause us prolonged sufferings": the role of good governance in building community resilience to natural disasters in Bangladesh. Journal of Environmental Planning and Management, 62 (10), 1761-1781 (2019).

10. I. Pal, \& R. Shaw, Disaster governance and its relevance. In I. Pal \& R. Shaw (Eds.), Disaster Risk Governance in India and Cross-Cutting Issues 3-22. Springer. (2018).

11. S. Jones, K. J. Oven, B. Manyena, \& K. Aryal, Governance struggles and policy processes in disaster risk reduction: a case study from Nepal. Geoforum, 57, 78-90 (2014).

12. A. D. Cook, V. Suresh, T. Nair, \& Y. N. Foo, Integrating disaster governance in Timor-Leste Opportunities and challenges. International Journal of Disaster Risk Reduction, 35, 1-41 (2019).

13. I. Pal, \& R. Shaw, Disaster governance and its relevance. In I. Pal \& R. Shaw (Eds.), Disaster Risk Governance in India and Cross-Cutting Issues, 3-22 Springer. (2018).

14. E. Samutereko, disaster preparedness, and Response in Zimbabwe the case of Cyclone Idai of March 2019 in Chipinge and Chimanimani. Technium Social Sciences Journal, 21, 877-885. (2021).

15. I. Pal, \& R Shaw, Disaster governance and its relevance. In I. Pal \& R. Shaw (Eds.), Disaster Risk Governance in India and Cross-Cutting Issues 3-22. Springer. (2018).
16. E. Z. Samutereko, Disaster preparedness, and Response in Zimbabwe: the case of Cyclone Idai of March 2019 in Chipinge and Chimanimani. Technium Social Sciences Journal, 21, 877-885. (2021).

17. S. Deen, Pakistan 2010 floods. Policy gaps in disaster preparedness and response. International Journal of Disaster Risk Reduction, 12, 341-349. (2015).

18. S. Jones, B. Manyena, \& S. Walsh, Disaster risk governance evolution and influences. In J. F. Shroder, A. E. Collins, ... J. Jayawickrama (Eds.), Hazards, risks and disasters in society, 45-61. Academic Press. (2015).

19. J. Maes, C. Parra, K. Mertens, B. Bwambale, L. Jacobs, J. Poesen, \& M. Kervyn, Questioning network governance for disaster risk management lessons learned from landslide risk management in Uganda. Environmental Science \& Policy, 85, 163171. (2018).

20. S. Jones, K. J. Oven, B. Manyena, \& K. Aryal, Governance struggles and policy processes in disaster risk reduction: a case study from Nepal. Geoforum, 57, 78-90. (2014).

21. D. N. Sonny, \& A. J. Manejar, Disaster preparedness and local governance in the Philippines (PIDS Discussion Paper Series, 2018-52 (2018).

22. D. N. Sonny, \& A. J. Manejar,. Disaster preparedness and local governance in the Philippines (PIDS Discussion Paper Series, No. 2018-52 (2018).

23. D. V. Blanco, Disaster governance in the Philippines issues, lessons learned, and future directions in the post-Yolanda super typhoon aftermath. International Journal of Public Administration, 38 (10), 743-756 (2015).

24. A. M. Acosta, A. Joshi, \& G. Ramshaw, Democratic accountability and service delivery: A desk review. International Institute for Democracy and Electoral Assistance. (2010).

25. D. Amaratunga, R. Haigh, \& S. Hettige, (Eds.). The Role of Accountability Within Disaster Risk Governance. Massey University. (2016).

26. M. Khotami, (Eds.). The Concept of Accountability in Good Governance. Atlantis Press. (2017).

27. M. Khotami, (Eds.). The Concept of Accountability in Good Governance. Atlantis Press. (2017).

28. M. Bovens, Analysing and assessing accountability: a conceptual framework. European Law Journal, 13 (4), 447-468 (2007).

29. K. S. Yap, What is Good Governance?. Bangkok United Nations Economic and Social Commission for Asia and the Pacific (UNESCAP). https://www.unescap.org/sites/default/files/goodgovernance.pdf (2007).

30. M. Khotami, (Eds.). (2017). The Concept of Accountability in Good Governance. Atlantis Press.

31. A. M. Acosta, A. Joshi, \& G. Ramshaw, Democratic accountability and service delivery: A desk review. 
International Institute for Democracy and Electoral Assistance. (2010).

32. A. M. Acosta, A. Joshi, \& G. Ramshaw, Democratic accountability and service delivery: A desk review. International Institute for Democracy and Electoral Assistance (2010).

33. D. Amaratunga, R. Haigh, \& S. Hettige, (Ed.). Accountability in the context of disaster risk governance. UNDRR. (2019).

34. B. Manin, A. Przeworski, \& S. Stokes, Elections and representation. In A. Przeworski, S. Stokes, \& B. Manin (Eds.), Democracy, accountability, and representation, 29-54 (1999).

35. A. M. Acosta, A. Joshi, \& G. Ramshaw, Democratic accountability and service delivery: A desk review. International Institute for Democracy and Electoral Assistance. (2010).

36. E. Zeyn, The effect of internal audit quality on financial accountability quality at local government. Journal of Accounting, Business and Finance Research, 4 (2), 74-82. (2018).

37. E. Zeyn. The effect of internal audit quality on financial accountability quality at local government. Journal of Accounting, Business and Finance Research, 4 (2), 74-82 (2018).

38. F. T., Khaile, \& G. J Davids,. The role of council committees in promoting financial accountability. Public Policy and Administration Research, 10 (8), 66-75 (2020).

39. E. Zeyn, The effect of internal audit quality on financial accountability quality at local government. Journal of Accounting, Business and Finance Research, 4 (2), 74-82. (2018)

40. N. Dewi, S. Azam,.\& S. Yusoff, Factors influencing the information quality of local government financial statement and financial accountability. Management Science Letters, 9 (9), 1373-1384 (2019).

41. D. W. Brinkerhoff, Accountability and good governance: concepts and issues. In A Huque \& H. Zafarullah (Eds.), International Development Governance 269-287. Routledge (2017).

42. A. M. Acosta, Joshi, A., \& Ramshaw, G. (2010). Democratic accountability and service delivery: $A$ desk review. International Institute for Democracy and Electoral Assistance.

43. D. W. Brinkerhoff, Accountability and good governance: concepts and issues. In A Huque \& H. Zafarullah (Eds.), International Development Governance, 269-287. Routledge. (2017)

44. D. Amaratunga, R. Haigh, \& S. Hettige, (Eds.). (2016). The Role of Accountability Within Disaster Risk Governance. Massey University.

45. D. Amaratunga, R. Haigh, \& S. Hettige,. (Eds.). (2016). The Role of Accountability Within Disaster Risk Governance. Massey University.

46. A. M. Acosta, A. Joshi, \& G. Ramshaw, Democratic accountability and service delivery: A desk review.
International Institute for Democracy and Electoral Assistance (2010).

47. A. M. Acosta, A. Joshi, \& G. Ramshaw. Democratic accountability and service delivery: A desk review. International Institute for Democracy and Electoral Assistance. (2010).

48. D. Amaratunga, R. Haigh, \& S. Hettige, (Ed.). Accountability in the context of disaster risk governance. UNDRR. (2019).

49. D. Amaratunga, R. Haigh, \& S. Hettige (Eds.). The Role of Accountability Within Disaster Risk Governance. Massey University. (2016).

50. D. Amaratunga, R. Haigh, \& S. Hettige (Eds.). The Role of Accountability Within Disaster Risk Governance. Massey University. (2016).

51. D. Amaratunga, R. Haigh, \& S. Hettige (Ed.). Accountability in the context of disaster risk governance. UNDRR (2019).

52. D. Amaratunga, R. Haigh, \& S. Hettige. (Ed.). Accountability in the context of disaster risk governance. UNDRR. (2019).

53. Philippine Disaster Risk Reduction and Management Act of 2010, Republic Act No. 10121 https://pcw.gov.ph/republic-act-10121-philippinedisaster-risk-reduction-and-management-act-of2010/ (2010).

54. D. Amaratunga, R. Haigh, \& S. Hettige. (Ed.). Accountability in the context of disaster risk governance. UNDRR. (2019).

55. Sendai Framework for Disaster Risk Reduction 2015-2030 United Nations Office for Disaster Risk Reduction.

https://www.preventionweb.net/files/43291_sendaif rameworkfordrren.pdf (2015).

56. Philippine Disaster Risk Reduction and Management Act of 2010, Republic Act No. 10121 https://pcw.gov.ph/republic-act-10121-philippinedisaster-risk-reduction-and-management-act-of2010/ (2010).

57. S. C. Opulencia-Calub, E. M., Luna, J. G. J. Molina, G. G. Pontejos, \& J. S. Chico, Tools, platforms and mechanisms to support accountability to disasteraffected populations in the Philippines. Institute of Development Studies. (2017).

58. S. C. Opulencia-Calub, E. M., Luna, J. G. J. Molina, G. G. Pontejos, \& J. S. Chico. STools, platforms and mechanisms to support accountability to disasteraffected populations in the Philippines. Institute of Development Studies. . (2017).

59. Philippine Disaster Risk Reduction and Management Act of 2010, Republic Act No. 10121 https://pcw.gov.ph/republic-act-10121-philippinedisaster-risk-reduction-and-management-act-of2010/ (2010).

60. affected populations in the Philippines. Institute of Development Studies. 